\title{
Quantitative and Qualitative Genetic Studies of Some Acacia Species Grown in Egypt
}

\author{
Nader R. Abdelsalam ${ }^{1, *(\mathbb{D}}$, Hayssam M. Ali ${ }^{2,3}{ }^{\mathbb{D}}$, Mohamed Z. M. Salem ${ }^{4, *(\mathbb{D}}$ and \\ Hosam E. El-Wakil ${ }^{1}$ \\ 1 Agricultural Botany Department, Faculty of Agriculture (Saba Basha), Alexandria University, \\ Alexandria 21531, Egypt; hosamelwakil@gmail.com \\ 2 Botany and Microbiology Department, College of Science, King Saud University, P.O. Box 2455, \\ Riyadh 11451, Saudi Arabia; hayhassan@ksu.edu.sa \\ 3 Timber Trees Research Department, Sabahia Horticulture Research Station, Horticulture Research Institute, \\ Agriculture Research Center, Alexandria 21526, Egypt \\ 4 Forestry and Wood Technology Department, Faculty of Agriculture (EL-Shatby), Alexandria University, \\ Alexandria 21545, Egypt \\ * Correspondence: nader.wheat@alexu.edu.eg (N.R.A.); zidan_forest@yahoo.com (M.Z.M.S.)
}

Received: 21 January 2020; Accepted: 11 February 2020; Published: 13 February 2020

\begin{abstract}
The objective of the current work is to study the genetic differentiation between Acacia species growing in Egypt as plant genetic resources based on morphological, biochemical, and molecular markers. The 20 replicates of Acacia tree collected from four localities from Egypt were A. tortilis ssp. raddiana and $A$. farnesiana (Siwa Oasis and Borg El-Arab City), A. stenophylla, A. sclerosperma (Marsa Matroh City), and A. saligna (Abis Station Farm, Alexandria). The results based on the previous markers indicated highly significant differences between Acacia species, confirming the hypothesis of the possibility of using morphological, biochemical, and molecular parameters in species identification. Qualitative characteristics results indicated some similarities and differences that are taxonomically important for comparing taxonomical grouping with morphological data for the genetic description of Acacia species. The activities of antioxidant enzymes have been studied intensively and the results provide strong similarities between the Acacia species (69\%), between A. raddiana (Siwa and Borg Al-Arab) and A. saligna, followed by all Acacia species (50\%). Finally, the molecular studies showed that a total of 563 amplification fragments, 190 fragments were monomorphic, and 373 fragments were polymorphic. The highest number of amplification fragments (21) was detected with OPB-20 primer, while OPA-20 showed seven amplification fragments; the average number was 13.09. The results indicated that Acacia species exhibit high genetic differentiation, helpful in the future for genetic improvement programs. The novelty of the current study is highlighting the importance of plant genetic resources in Egypt and using different techniques to measure the differentiation between these species.
\end{abstract}

Keywords: acacia species; isozyme; morphology; plant genetic; genetic differentiation; RAPD-PCR; qualitative characteristics

\section{Introduction}

Egypt is well known for its expansive desert, as approximately $80 \%$ of the country is desert. This desert is largely composed of sand dunes, sheets, bed rock, sandstone, limestone, and salt marshes. In the western desert of Egypt, there are a series of oases stretching longitudinally from the north to the far south in a line almost parallel to the Nile valley. This represents natural depressions rich in natural springs and wells that can be used for agriculture. One of the advantages of this desert is the presence of wild flora adapted to biotic stresses such as high temperature, drought, and salinity. 
Despite the rarity of wild plant cover in such regions, the existing flora is a trove of genetic resources. Most of these floral species are considered the ancestors of domesticated plants, while others possess medicinal benefits, either at a popular level or as documented medicinal treatments. Acacia tortilis ssp. raddiana is growing in Siwa Oasis as wild flora. By the end of the 21st century, the plant life in the oases of Egypt will have completely changed; about 500,000 acres are expected to be reclaimed and cultivated after redirecting the Nile water to these areas through the Toschka canal from Lake Nasser (south of Aswan on the Nile Valley) to the Kharga Oasis, and ending in the Farafra Oasis in the Western Desert. The importance of plant conservation within and beyond protected areas and the impacts of global change on protected areas and on species conservation have been shown [1]. Albrecht and Long [2] worked on the legume plants and showed the habitat suitability and herbivores determination of legume species. Shaw [3] showed the importance of diversity in plants and species diversity in restoration plantings, in addition to the other important factors to increase the genetic diversity of threatened tree species

Acacia trees constitute much of the woody vegetation plant communities [4]. In addition to their environmental values regarding soil fixation and fertility, considerable research has focused on the silviculture of Acacia species, due to their wide distribution in arid regions and various uses, including fodder, fuel, and medicine [5].

Acacia is the second-largest genus in the family Leguminosae, with nearly 1350 species [6,7]. The current classification of Acacia consists of three subgenera [7]: Acacia, Aculeiferum and Heterophyllum (=Phyllodineae). The base chromosome number in the genus Acacia is $26(\mathrm{x}=13)$, with polyploidy occurring in several species [8,9]. Vivi Tackholm [10] reported that Acacia consisted of 11 different species in Egypt, the most well-known being A. nilotica L. species A. mellifera, A. laeta, A. glaucophylla, A. albida, A. tortilis, A. raddiana, A. nubica, A. seyal, A. flave, and A. etbaice. These species occupy vast areas of the Nile Valley and Nile Delta.

Previous studies on Acacia seeds suggested that Acacia species are a possible source of protein for humans [11]. Acacias can produce crude protein per hectare more than many grain crops. For example, the protein content of A. mellifera (41.6\%) is close to that of soybean (42.8\%) [12].

Peroxidase iso-enzyme assay was determined to be the most appropriate technique for the evaluation of the assessed wild and domesticated acacia. Classified peroxidase patterns were ascribed to different phenotypes. As conventional symbols in electrophoresis analysis, a pattern was first described in terms of anodal (A) or cathodal (C) zones according to their direction of mobility under electrophoresis. A study of genetic polymorphism in the peroxidase enzyme system was conducted on the Acacia plants [13].

The activities of antioxidant enzymes have been studied intensively. However, the significance of these enzymes in salt tolerance is still a matter of controversy, as high-antioxidant enzymatic activities have been associated with salt tolerance as well as salt sensitivity. This led to the suggestion that genetic differences in salt tolerance among plants are not necessarily due to differences in their ability to detoxify $\mathrm{ROS}_{4}$, despite the large number of studies that correlate efficient antioxidative defense with salt tolerance [14]. Isozyme loci have been used as markers in many genetic studies, such as those on genetic diversity in Brassica juncea [15] and seed coat color [16]. Peroxidases are enzymes related to polymer synthesis in the cell wall [17] and play a role in the prevention of oxidative damage caused by environmental stress to membrane-bound lipids [18]. Wisal et al. [19] estimated the intra- and inter-specific genetic variability between four species of Family Fabaceae. They used morphometric and protein profiling to detect the variations between these different species.

Plant peroxidases have been used as biochemical markers for various types of biotic and abiotic stresses due to their role in critical physiological processes, such as the control of growth by lignification, crosslinking of pectins and structural proteins in the cell wall, and catabolism of auxins [20]. Catalases and superoxide dismutases are the most efficient antioxidant enzymes [21]. The morphological and genetic diversities among A. aroma, A. macracantha, A. caven, and A. furcatispina were studied using morphometric, isozymal, and random amplified polymorphic DNA (RAPD) 
approaches by Casiva et al. [22]. The analysis of seven isozyme systems revealed 21 loci, and RAPD analysis showed 34 loci. Most of these loci allowed us to differentiate species, except for A. aroma and A. macracantha, the two most similar species. The levels of genetic variability estimated by isozymes were higher than those determined from RAPD analyses. Morphometric characteristics were highly significantly different among the species, although A. aroma and A. macracantha were differentiated only by thorn length.

Proline is an amino acid and compatible solute that commonly accumulates in many plants exposed to various stress conditions, such as salinity. When a plant is subjected to stressful conditions, proline is synthesized from glutamate due to the loss of feedback regulation in the proline biosynthetic pathway [23]. The measurement of proline accumulation is an important criterion for determining plant tolerance to salt stress [24]. In salt-stressed plants, the osmotic potential of the vacuoles is reduced by proline accumulation [25]. It is believed that proline accumulation under environmental stress does not inhibit biochemical reactions and plays a protective role during osmotic stress [25]. It is suggested that low osmotic potential may cause proline accumulation in tissues [26].

Modern tools in molecular biology provide detailed information about the genetic structure of natural populations, which was previously not available. During domestication, genetic variation in crop plants decreased due to continuous selection pressure for traits such as great yield or disease resistance. It is necessary to compare the genetic composition of the germplasm of existing cultivars to their ancestors and related species. Genetic differentiation among populations is principally a function of gene flow via pollen and seed dispersal. Several authors have studied the taxonomy of Acacia using morphological characteristics [27]. In the last decade, some studies have alternatively used biochemical and molecular markers [28]. Biochemical and molecular studies have been conducted on African and Australian Acacia species to provide markers useful for plant breeding and conservation programs [29]. Isozyme electrophoresis and random amplified polymorphic DNA (RAPD) analysis are broadly used in plant population genetic studies [30]. RAPD has primarily enabled the resolution of complex taxonomic relationships [31]. Additionally, phylogenetic diversity is recognized as a relevant criterion for the conservation of species [32]. Analysis of genetic variation in different plant species was carried out by Attia and Al-Sodany [33], who studied the ecological distribution, and, in addition, genetic variations, of some Aloe species based on RAPD and SSR markers. Asaf et al. [34] detected the complete chloroplast genomes of Vachellia nilotica and Senegalia senegal and they recorded that this may help to elucidate the genome architecture of these species and evaluate the genetic diversity among species.

Acacia species are useful as livestock fodder [35] —Bedouin use Acacia leaves and pods for fuel, fodder, and medicine-but there are issues with the identification of species. Genetic descriptions and phylogenetic relationships among Acacia species are particularly valuable for the conservation management of evolutionarily diverse flora [36]. Genetic differentiations in plant growing in Egypt were studied based on horticulture, molecular and morphological markers [37]. Genetic variation and differentiation in many plants species were studied based on morphological, biochemical, and molecular markers such as tea (Camellia sinensis), and revealed by RAPD and AFLP variation by Wachira et al. [38]; Cornus florida L using Isozyme and morphological variation [39]; Cornus [40]; genetic markers and horticultural germplasm management [41]; genetic diversity of Salvia species [42]; micropropagation of A. chundra (Roxb.) [43]; genetic diversity and differentiation of invasive A. longifolia in Portugal [44]; microsatellite markers used for $A$. senegal [45]; phylogenetic analysis based on nuclear DNA and morphology definitions of eastern Australian species of Acacia [46]; phylogenetic connections of phyllodinous species of Acacia outside Australia [47]; assessment of the phenology of A. longifolia [48]; characterization of microsatellite markers used for tree legume $A$. koa [49]; genetic diversity of Australian acacias [50]; genetic diversity of $A$. senegal (L.) willd in Kenyan populations combined RAPD and ISSR markers [51]; genetic diversity and structure of A. senegal (L.) Willd. in Uganda [52,53]; molecular phylogeny of Acacia s.s. [54]; genetic consequences of anthropogenic disturbances and population fragmentation in A. senegal [55]; isolation and characterization of SSR markers in the East African tree, A. brevispica [56], and genetic variation in natural populations of $A$. visco [57]. Taylor and Dhileepan [58] 
showed the effect of the change in phylogenetic relationships of Acacia species on the biological control of Vachellia nilotica ssp. Also, Monks et al. [59] studied the recovery of some threatened plant species and their habitats in the biodiversity hotspot of the Southwest Australian Floristic Region.

The present study investigated the genetic description and phylogeny of some Egyptian Acacia species and subspecies by calculating the morphological, quantitative, and qualitative variations among the species, detecting the biochemical markers based on peroxidase activity and proline content, and estimating the level of polymorphism using RAPD-PCR markers.

\section{Results and Discussion}

\subsection{Morphological Variations of Acacia Species}

The morphological variations among five Acacia species (A. farnesiana, A. tortilis ssp. raddiana, A. saligna, A. sclerosperma, and A. stenophylla) were determined, and the results are illustrated in Table 1. Some morphological differentiations were also recorded in Figures 1 and 2.

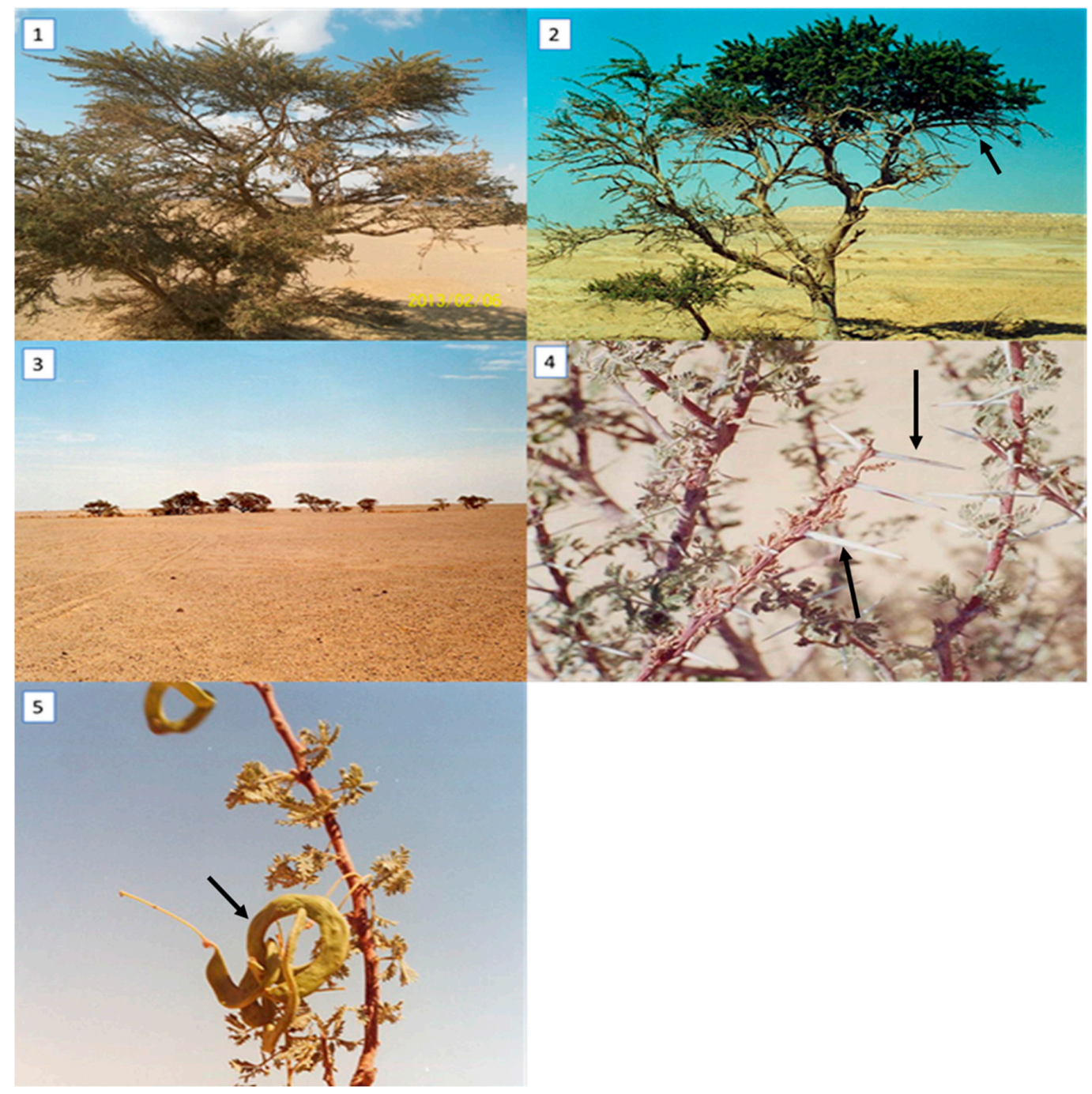

Figure 1. Morphological description of Acacia species growing in Egypt (1-5) Acacia tortilis ssp. raddiana (collected from Siwa Oasis, an urban oasis in Egypt between the Qattara Depression and the Great Sand Sea in the Western Desert nearly $50 \mathrm{~km}$ east of the Libyan border and $650 \mathrm{~km}$ from Cairo, $29^{\circ} 12^{\prime} 19 \mathrm{~N}$ $25^{\circ} 31^{\prime} 10 \mathrm{E} 29^{\circ} 12^{\prime} 19 \mathrm{~N} 25^{\circ} 31^{\prime} 10 \mathrm{E}$ ). (1-3) showing the growth stage of Acacia under the desert conditions and (2, 4 and 5) arrows point to the different pine and pinna and show the difference in leaf length, pinna length and spine length. Photos were taken by Coauthor Nader R. Abdelsalam. 

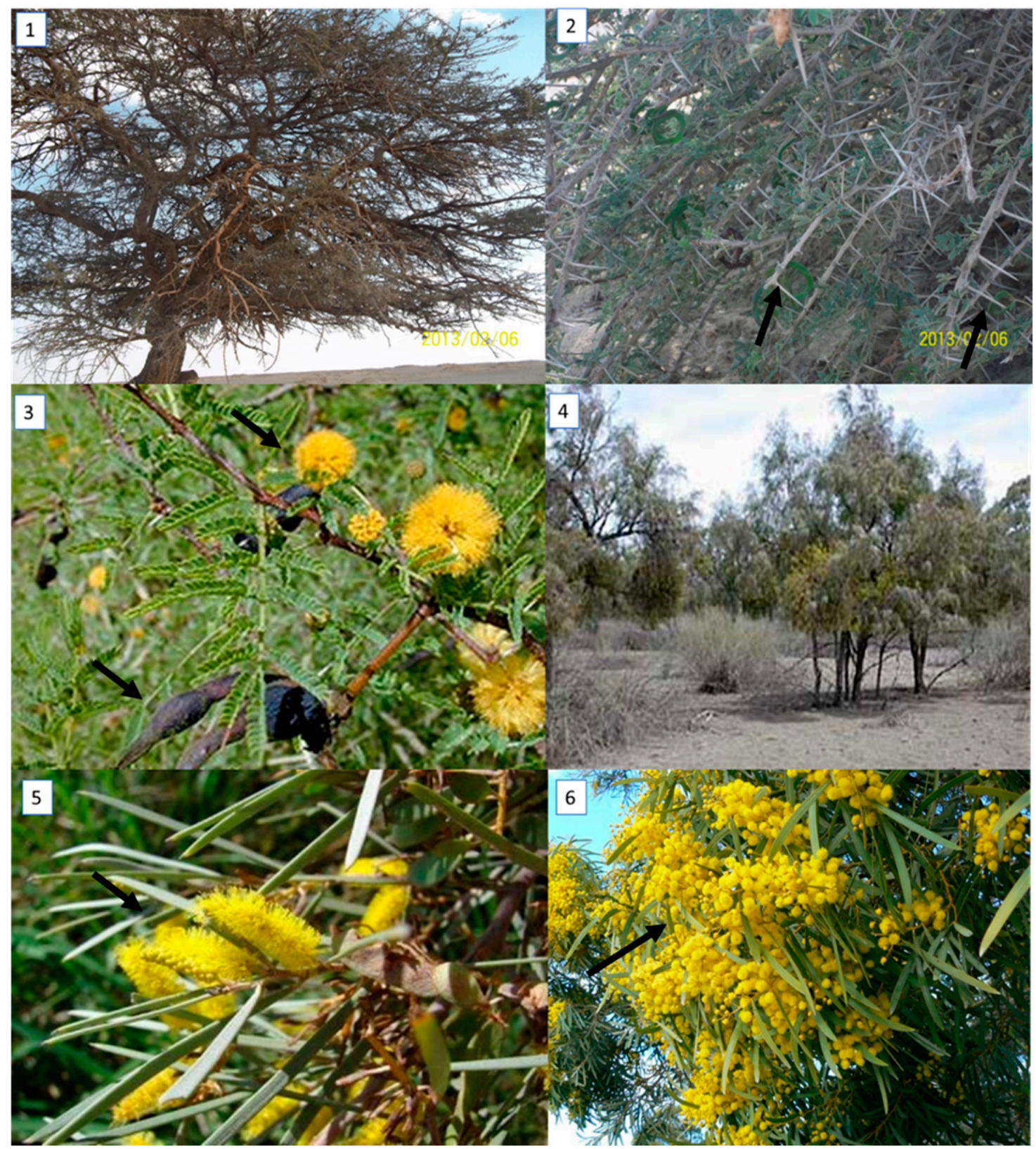

Figure 2. Morphological variations of Acacia species growing in Egypt, i.e., (1-2) A. tortilis ssp. raddiana (Borg Al-Arab, $48 \mathrm{~km}$ south-west of central Alexandria and $7 \mathrm{~km}$ Mediterranean Coast, $30^{\circ} 50^{\prime} 56 \mathrm{~N}$ $29^{\circ} 36^{\prime} 42 \mathrm{E}$ ), arrows point to the different pine and pinna and show the difference in tree form and leaf length, pinna length and spine length, (3) A. stenophylla (Marsa Matroh City, $240 \mathrm{~km}$ west of

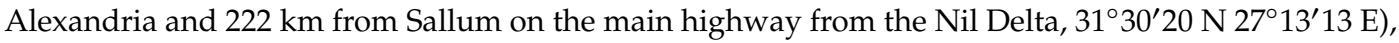
(4) A. farnesiana (Borg El-Arab city), (5) A. sclerosperma (Marsa Matroh City), and (6) A. saligna (Abis Station Farm, Alexandria, $31^{\circ} 12$ N $29^{\circ} 55$ E) showing the flowering stage. Photos were taken by Coauthor Nader R. Abdelsalam.

Regarding these parameters, ANOVA revealed very significant differences among the Acacia species, confirming the hypothesis of the possibility of identification from such vegetative characteristics. Concerning spine length $(\mathrm{mm})$, data in Table 1 clearly indicate highly significant variation among the different species. We recorded the longest spines in A. tortilis ssp. raddiana (collected from Siwa Oasis), followed by A. tortilis ssp. raddiana (Borg Al-Arab city), with means of 28.7 and $19.3 \mathrm{~mm}$, respectively. The shortest spines were found in A. farnesiana, i.e., $6.5 \mathrm{~mm}$. No spines were present in the other three species; A. saligna, A. sclerosperma, and A. stenophylla had no spines. 
Table 1. Morphological variations of Acacia species: spine length, pinna length, leaf length and leaflet length.

\begin{tabular}{ccccc}
\hline Species & Spine Length $(\mathbf{m m})$ & Pinna Length $(\mathbf{c m})$ & Leaf Length $(\mathbf{c m})$ & Leaflet Length $(\mathbf{m m})$ \\
\hline A. tortilis ssp. raddiana $^{* *}$ & $28.75^{\mathrm{a}} \pm 0.33$ & $0.68^{\mathrm{c}} \pm 0.01$ & $2.85^{\mathrm{e}} \pm 0.05$ & $2.00^{\mathrm{a}} \pm 0.01$ \\
\hline A. tortilis ssp. raddiana $^{* * *}$ & $19.25^{\mathrm{b}} \pm 0.15$ & $0.98^{\mathrm{b}} \pm 0.01$ & $3.15^{\mathrm{e}} \pm 0.11$ & $2.50^{\mathrm{a}} \pm 0.01$ \\
\hline A. farnesiana & $6.50^{\mathrm{c}} \pm 0.16$ & $4.28^{\mathrm{a}} \pm 0.65$ & $3.80^{\mathrm{d}} \pm 0.08$ & $2.25^{\mathrm{a}} \pm 0.11$ \\
\hline A. saligna & - & - & $23.28^{\mathrm{b}} \pm 1.30$ & - \\
\hline A. sclerosperma & - & - & $26.08^{\mathrm{a}} \pm 1.00$ & - \\
\hline A. stenophylla & - & - & $19.25^{\mathrm{c}} \pm 1.77$ & - \\
\hline LSD 0.05 & 1.36 & 0.252 & 0.508 & 0.705 \\
\hline
\end{tabular}

${ }^{*}$ Mean followed by the same letter (s) is not significantly different at 0.05 levels. (-) not found, ${ }^{* *} A$. tortilis ssp. raddiana (Siwa Oasis), ${ }^{* * *}$ A. tortilis ssp. raddiana (Borg Al-Arab).

The results in Table 1 demonstrate an inverse relationship between the spine and pinna length, especially in the desert localities, where these species grow under very unfavorable conditions of drought and high salinity. A. tortilis ssp. raddiana collected from Siwa and Borg Al-Arab had the shortest pinna length $(0.68$ and $0.98 \mathrm{~cm}$, respectively) and $A$. farnesiana had the longest pinna length $(4.3 \mathrm{~cm})$. As per the phyllode length $(\mathrm{cm})$ data in Table 1, A. sclerosperma and A. saligna had the longest mean leaf length values of $19.3 \mathrm{~cm}$ and $26.1 \mathrm{~cm}$, respectively. The mean shortest leaf lengths recorded were $2.85 \mathrm{~cm}$ for $A$. tortilis ssp. raddiana collected from (Siwa), $3.2 \mathrm{~cm}$ for A. tortilis ssp. raddiana collected from Borg Al-Arab, and finally $3.80 \mathrm{~cm}$ for A. farnesiana. The means ranged from 2.0 to $2.5 \mathrm{~mm}$ for $A$. tortilis ssp. raddiana (collected from Siwa Oasis $=2 \mathrm{~mm}$ ), followed by $A$. tortilis ssp. raddiana (collected from Borg Al-Arab $=2.50)$ and A. farnesiana $(2.25 \mathrm{~mm}$ ).

Based on the morphological characterization (via qualitative description) we found some similarities and differences that are taxonomically important for comparing taxonomical grouping with morphological data for the genetic description of Acacia species. Based on the qualitative results, there were high similarities between $A$. farnesiana and $A$. tortilis ssp. raddiana, as both species possessed pinnately compound leaves. On the other hand, A. saligna, A. sclerosperma, and A. stenophylla had simple leaves (Table 2). The same trend was observed for the growth type, with shrub/small trees being compared to other species that were shrubs or trees. The highest number of stems was recorded for A. farnesiana (2-5 stems), followed by both $A$. tortilis ssp. (1-4 stems) and A. stenophylla (typically 1 stem). Concerning spine shape, the spines were small in A. farnesiana but were long, white, and straight in both $A$. tortilis ssp., as shown in Figures 1 and 2.

Table 2. Qualitative description of some Acasia species in Egypt.

\begin{tabular}{cccccc}
\hline Species & Leaves Type of & Growth Form & Crown Shape & $\begin{array}{c}\text { Mean of Stems } \\
\text { Number }\end{array}$ & $\begin{array}{c}\text { Spine S } \\
\text { Hape }\end{array}$ \\
\hline A. tortilis ssp. raddiana $^{*}$ & $\begin{array}{c}\text { Pinnately } \\
\text { compound }\end{array}$ & $\begin{array}{c}\text { Shrub/small } \\
\text { tree }\end{array}$ & irregular/round & $3 \pm 0.12$ & $\begin{array}{c}\text { Long white } \\
\text { straight }\end{array}$ \\
\hline A. tortilis ssp. raddiana ** & $\begin{array}{c}\text { Pinnately } \\
\text { compound }\end{array}$ & $\begin{array}{c}\text { Shrub/small } \\
\text { tree }\end{array}$ & irregular/round & $2.5 \pm 0.02$ & $\begin{array}{c}\text { Long white } \\
\text { straight }\end{array}$ \\
\hline A. farnesiana & $\begin{array}{c}\text { Pinnately } \\
\text { compound }\end{array}$ & $\begin{array}{c}\text { Shrub/small } \\
\text { tree }\end{array}$ & $\begin{array}{c}\text { often } \\
\text { spread }\end{array}$ & $3.5 \pm 0.26$ & small \\
\hline A. saligna & Simple & shrub or tree & spread & $1 \pm 0.01$ & - \\
\hline A. sclerosperma & Simple & shrub or tree & spread & $1 \pm 0.01$ & - \\
\hline A. stenophylla & Simple & shrub or tree & rounded & $1 \pm 0.00$ & - \\
\hline$*$ A. tortilis ssp. raddiana (Siwa Oasis), ${ }^{* *}$ A. tortilis ssp. raddiana (Borg Al-Arab). &
\end{tabular}


Morphological studies were conducted on Acacia species in different Arabian countries, such as Morocco, by El Ayadi et al. [60]. In their study, the authors assessed the variability in eight pod traits of 300 genotypes (mother-tree) of $A$. tortilis ssp. raddiana (Savi) 'Brenan', collected from the southern regions of Morocco. The ANOVA results showed that $A$. raddiana exhibited significant differences in traits due to genotypes within provenances, i.e., in the pod length, seed weight per pod, seed number per pod, infected seed number per pod, and 100-seed weight.

In general, the phenotypic coefficient of variation was higher than the genotypic coefficient of variation, indicating the predominant role of the environment. Their results also demonstrated great heritability and genotypic gain for the 100-seed weight ( $92.75 \%$ and $17.20 \%$, respectively), empty pod weight (53.68\% and $21.18 \%$, respectively), and pod weight ( $46.45 \%$ and $16.13 \%$, respectively), indicating additive gene action.

Our results are consistent with those of Quentin et al. [61], who reported that $A$. saligna grows as a small, dense, sprawling tree with a short trunk and a weeping habit. It grows up to $8 \mathrm{~m}$ in height. Like many Acacia species, it has phyllodes rather than true leaves and these phyllodes can reach a length of $25 \mathrm{~cm}$.

\subsection{Biochemical Analysis}

\subsubsection{Isozyme Assay}

Peroxidase isozymes exhibited a wide range of variability among the different species at different localities (that ranged in Siwa from deep depression that reaches blew sea level, to about -19 matters, to hot semi-arid climate with moderate temperatures in Alexandria, to hot desert climate in Marsa Matruh). One cathodal (Pex.c1) band was observed as a common band for all samples. The results revealed five anodal (Pex.a1; Pex.a2; Pex.a3, Pex.a4, and Pex.a5) bands recorded for all species. Pex.a1 was recorded in A. farnesiana specie, Pex.a2 was recorded in A. tortilis ssp., and Pex.a3 was recorded in both A. stenophylla, and A. sclerosperma, and Pex.a5 was observed in A. sclerosperma (Figure 3).

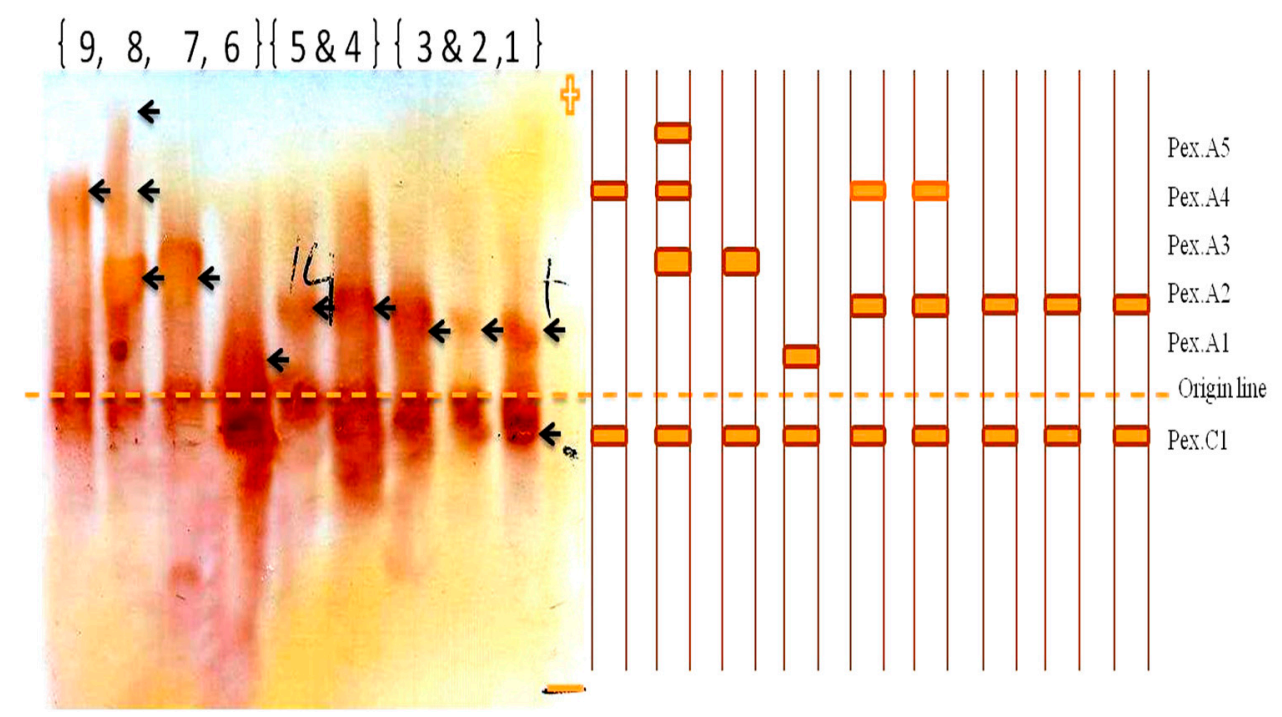

Figure 3. Zymograme of peroxidase isozyme of Acacia ssp. (1, 2 and 3) tortilis ssp. raddiana (Siwa), (4\&5) tortilis ssp. raddiana (Borg El-Arab), (6) A. farnesiana, (7) A. stenophylla, (8) A. sclerosperma and (9) A. saligna.

The data indicate that the peroxidase patterns in the leaves of wild A. raddiana (Siwa) and the five domesticated Acacia species showed two kinds of banding profiles. First, it was evident that all plants expressed Px.c1, and the five domesticated plants exhibited the same banding profile containing this one locus. This indicated that one common locus was consistently monomorphically expressed. 
Second, the $A$. raddiana (Siwa) wild types shared one common locus (Px.a1). The banding pattern activity of Acacia displayed a unique marker band at the Px.1a and Px.5a loci, indicating that the Px.a2, Px.a3, and Px.a4 loci are specifically polymorphic. The similarity and genetic distance of Acacia spp. are presented in Figure 4.

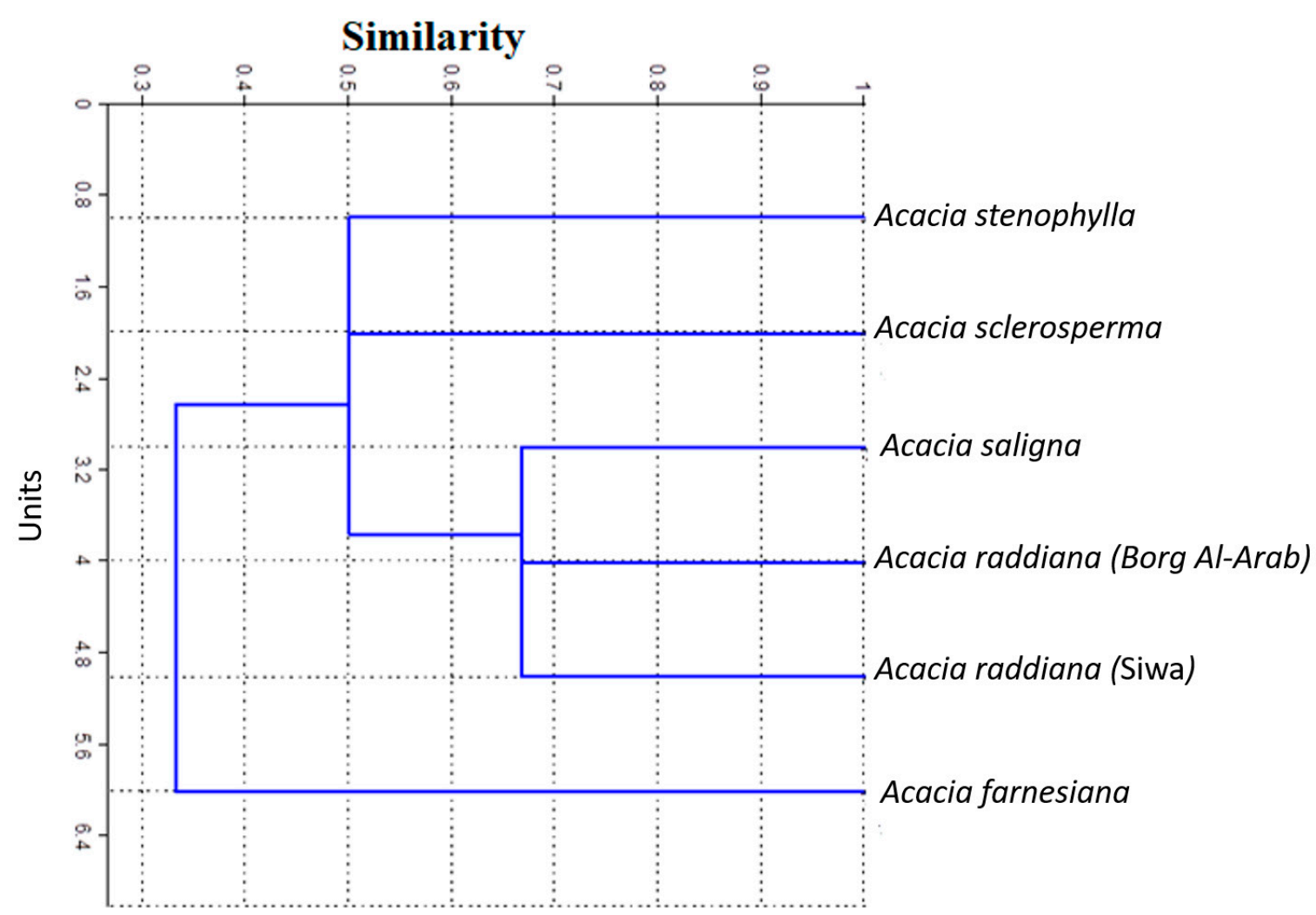

Figure 4. Similarity and genetic distance of Acacia spp. Under the certain study.

Bands common among all examined species were estimated using average values and were standardized prior to cluster analysis. Data shown in Figure 4 reveal strong similarities among the Acacia species located in the first cluster (69\%), between A. raddiana (Siwa and Borg Al-Arab) and A. saligna, followed by all Acacia species (50\%) in the last cluster (except for A. farnesiana), and the similarity between all Acacia species was 33\%. Salt stress was found to increase the intensity of the peroxidase bands. A. tortilis ssp. raddiana exhibited greater band intensity compared to the other species.

\subsubsection{Proline Content}

The highest content according the Table 3, A. tortilis ssp. raddiana (Siwa Oasis) had the highest proline content $(43.4 \mu \mathrm{mol} / \mathrm{g}$ fresh weight), whereas $A$. sclerosperma had the lowest value $(7.6 \mu \mathrm{mol} / \mathrm{g}$ fresh weight) (Table 3). There was highly significant variation among all species in relation to the proline content, and this variation was associated with environmental effects and conditions. Acacia tortilis ssp. raddiana (Borg Al-Arab) had the highest proline content $(23.1 \mu \mathrm{mol} / \mathrm{g}$ fresh weight). The results supported the conclusion that proline accumulates in greater concentrations in plants growing in salty, dry soil and may be useful as a salt injury indicator in plants. This variation in proline could be useful in the selection for salt tolerance and as a marker of salt-tolerant plants. Genotypic variations in proline accumulation have been observed [62], and attempts have been made to correlate its accumulation with stress tolerance in plants. This apparent correlation between proline accumulation and environmental stress suggests that proline might exhibit a protective function [63]. 
Table 3. Proline content ( $\mu \mathrm{mol} / \mathrm{g}$ fresh weight) in some Acacia species.

\begin{tabular}{cc}
\hline Species & Proline Content $(\mu \mathrm{mol} / \mathbf{g}$ Fresh Weight) \\
\hline A. tortilis ssp. raddiana (Siwa) & $43.4^{\mathrm{a}}$ \\
\hline A. tortilis ssp. raddiana (Borg Al-Arab) & $23.1^{\mathrm{b}}$ \\
\hline A. stenophylla & $21.7^{\mathrm{c}}$ \\
\hline A. farnesiana & $13.1^{\mathrm{d}}$ \\
\hline A. saligna & $11.5^{\mathrm{e}}$ \\
\hline A. sclerosperma & $7.6^{\mathrm{f}}$ \\
\hline LSD 0.05 & 0.282 \\
\hline Mean followed by the same letter $(\mathrm{s})$ is not significantly different at 0.05 levels.
\end{tabular}

\subsection{Molecular Markers (RAPD-PCR)}

Random Amplified Polymorphic DNA (RAPD) Analysis

In the present study, the genetic variability and relationships of different Acacia species were studied based on RAPD analysis. The initial screening of 52 primers with six samples resulted in 43 primers that produced informative and polymorphic products resolvable by agarose gel electrophoresis (Table 4). Profile examples of Acacia species on agarose gel, amplified with RAPD primers, are found in (Figure 5).
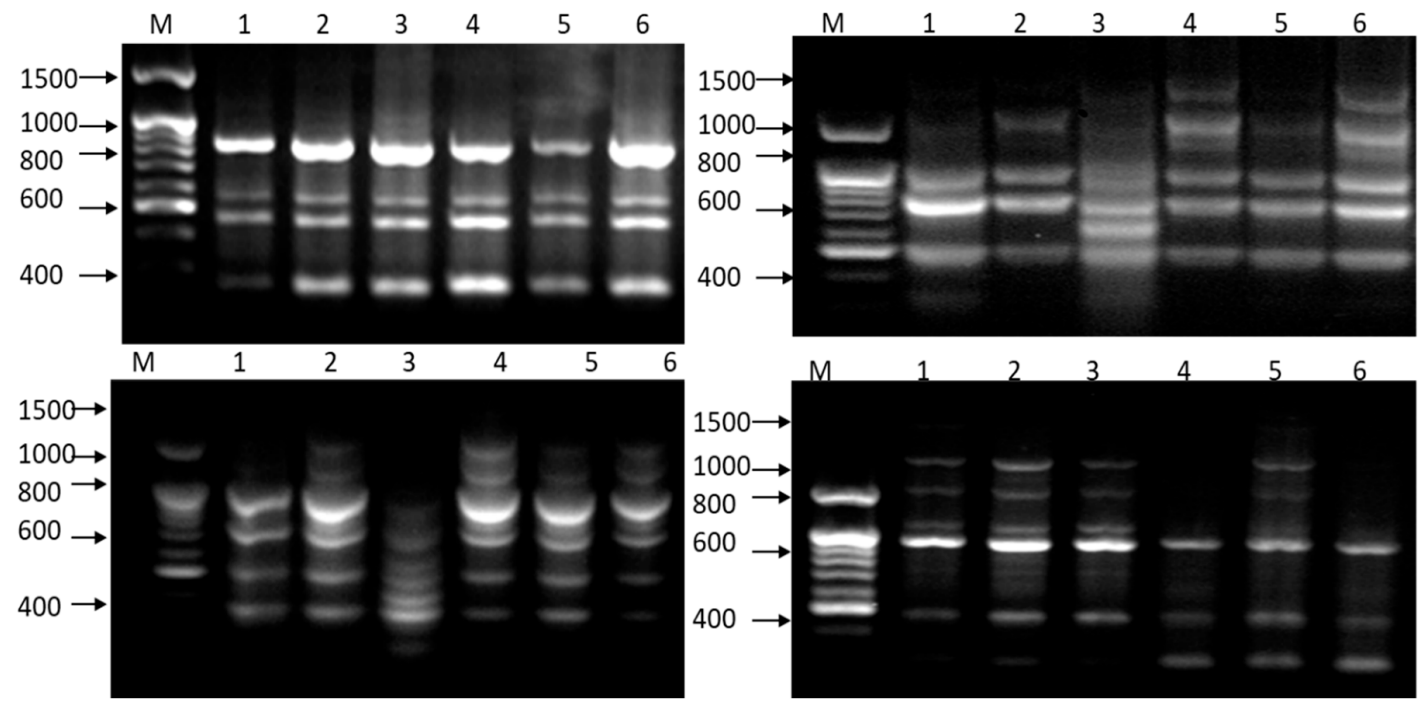

Figure 5. Profile examples of Acacia species on agarose gel, amplified with RAPD primers, i.e., OPB-03, OPB-17, OPB-20 and OPQ-12. M = Molecular marker (200: 1500 bp), (1) A. tortilis ssp. raddiana (Siwa Oasis), (2) A. tortilis ssp. raddiana (Borg Al-Arab), (3) A. stenophylla, (4) A. farnesiana, (5) A. sclerosperma and (6) A. saligna.

Out of 563 amplification fragments, 190 fragments were monomorphic, and 373 fragments were polymorphic (Table 4). The maximum number of amplification fragments recorded was 21 for primer OPB-20, compared with the lowest, i.e., seven for primer OPA-20. The average number of amplification fragments was 13.09 for all 43 primers (Table 4).

Concerning the monomorphic fragments, eight was the highest number of fragments recorded with primers OPB-03 and OPN-04, and one was the lowest number of fragments recorded for primer OPA-20. The general mean of the monomorphic fragments was 4.42 for all primers. Regarding polymorphic fragments, 14 was the highest value, recorded for primers OPA-16, OPB-20 and OPQ-14, while four fragments was the lowest detected value (OPA-09). The average number of polymorphic amplification fragments was 8.67 (Table 4). 
Table 4. Primer name, sequence, total number of amplified fragments and polymorphic percentage for Acacia species based on RAPD analysis.

\begin{tabular}{|c|c|c|c|c|c|c|c|}
\hline Premier Number & Primer Name & Sequence $3^{\prime}-5^{\prime}$ & TAF & MF & PF & PIC\% & Size (Kbp) \\
\hline 1 & OPA-01 & 5'-CAGGCCCTTC-3' & 09 & 02 & 07 & 77.78 & $0.1-2.9$ \\
\hline 2 & OPA-02 & 5'-TGCCGAGCTG-3' & 09 & 03 & 06 & 66.67 & $0.2-2.6$ \\
\hline 3 & OPA-05 & 5'-AGGGGTCTTG-3' & 11 & 07 & 05 & 45.45 & $0.1-2.6$ \\
\hline 4 & OPA-09 & 5'-GGGTAACGCC-3' & 08 & 04 & 04 & 50.00 & $0.2-2.5$ \\
\hline 5 & OPA-11 & 5'-CAATCGCCGT-3' & 13 & 05 & 08 & 61.54 & $0.1-3.0$ \\
\hline 6 & OPA-14 & 5'-TCTGTGCTGG-3' & 13 & 03 & 10 & 76.92 & $0.1-2.8$ \\
\hline 7 & OPA-15 & 5'-TTCCGAACCC-3' & 16 & 06 & 10 & 62.50 & $0.1-2.7$ \\
\hline 8 & OPA-16 & 5'-AGCCAGCGAA-3' & 19 & 04 & 14 & 73.68 & $0.3-2.6$ \\
\hline 9 & OPA-18 & 5'-AGGTGACCGT-3' & 09 & 02 & 07 & 77.78 & $0.1-2.6$ \\
\hline 10 & OPA-20 & 5'-GTTGCGATCC-3' & 07 & 01 & 06 & 85.71 & $0.1-2.9$ \\
\hline 11 & OPB-03 & 5'-CATCССССТG-3' & 18 & 08 & 10 & 55.56 & $0.2-3.0$ \\
\hline 12 & OPB-07 & 5'-GAAACGGGTG-3' & 16 & 05 & 11 & 68.75 & $0.2-2.2$ \\
\hline 13 & OPB-17 & 5'-AGGGAACGAG-3' & 18 & 06 & 12 & 66.67 & $0.2-2.3$ \\
\hline 14 & OPB-20 & 5'-GGACCCTTAC-3' & 21 & 07 & 14 & 66.67 & $0.2-2.4$ \\
\hline 15 & OPC-02 & 5'-GTGAGGCGTC-3' & 15 & 05 & 10 & 66.67 & $0.1-2.3$ \\
\hline 16 & OPC-05 & 5'-GATGACCGCC-3' & 10 & 03 & 07 & 70.00 & $0.1-2.3$ \\
\hline 17 & OPC-12 & $5^{\prime}$-TGTCATCCCC-3' & 11 & 04 & 07 & 63.64 & $0.1-2.3$ \\
\hline 18 & OPC-16 & 5'-CACCATCCAG-3' & 10 & 04 & 06 & 60.00 & $0.1-2.3$ \\
\hline 19 & OPD-03 & 5'-GTCGCCGTCA-3' & 13 & 05 & 08 & 61.54 & $0.3-2.5$ \\
\hline 20 & OPD-04 & 5'-TCTGGTGAGG-3' & 13 & 04 & 09 & 69.23 & $0.3-2.6$ \\
\hline 21 & OPD-05 & 5'-TGAGCGGACA-3' & 14 & 04 & 10 & 71.43 & $0.1-2.9$ \\
\hline 22 & OPD-08 & 5'-GTGTGCCCCA-3' & 13 & 04 & 09 & 69.23 & $0.2-2.9$ \\
\hline 23 & OPD-11 & 5'-AGCGCCATTG-3' & 12 & 03 & 09 & 75.00 & $0.1-2.5$ \\
\hline 24 & OPE-12 & $5^{\prime}$-TTATCGCCCC-3' & 15 & 06 & 09 & 60.00 & $0.3-2.4$ \\
\hline 25 & OPG-12 & 5'-CAGCTCACGA-3' & 15 & 03 & 12 & 80.00 & $0.3-2.6$ \\
\hline 26 & OPH-11 & 5'-AGCGCCATTG-3' & 11 & 05 & 06 & 54.55 & $0.3-2.9$ \\
\hline 27 & OPN-04 & 5'-GACCGACCCA-3' & 14 & 08 & 06 & 42.86 & $0.1-2.6$ \\
\hline 28 & OPN-05 & 5'-ACTGAACGCC-3' & 13 & 06 & 07 & 53.85 & $0.1-2.7$ \\
\hline 29 & OPN-08 & 5'-ACCTCAGCTC-3' & 13 & 06 & 07 & 53.85 & $0.2-2.7$ \\
\hline 30 & OPN-09 & 5'-TGCCGGCTTG-3' & 12 & 05 & 07 & 58.33 & $0.1-2.9$ \\
\hline 31 & OPN-10 & 5'-ACAACTGGGG-3' & 15 & 04 & 11 & 73.33 & $0.2-2.0$ \\
\hline 32 & OPN-11 & 5'-ACAACTGGGG-3' & 14 & 04 & 10 & 71.43 & $0.1-3.0$ \\
\hline 33 & OPN-13 & 5'-AGCGTCACTC-3' & 10 & 03 & 07 & 70.00 & $0.2-3.0$ \\
\hline 34 & OPN-14 & 5'-TCGTGCGGGT-3' & 10 & 02 & 08 & 80.00 & $0.2-2.9$ \\
\hline 35 & OPN-15 & 5'-CAGCGACTGT-3' & 10 & 02 & 08 & 80.00 & $0.1-2.8$ \\
\hline 36 & OPN-16 & 5'-AAGCGACCTG-3' & 09 & 02 & 07 & 77.78 & $0.1-2.7$ \\
\hline 37 & OPN-17 & 5'-AGCGTCACTC-3' & 11 & 05 & 06 & 54.55 & $0.1-2.7$ \\
\hline 38 & OPM-05 & 5'-GGGAACGTGT-3' & 14 & 04 & 10 & 71.43 & $0.1-2.7$ \\
\hline 39 & OPQ-12 & 5'-AGTAGGGCAC-3' & 19 & 07 & 12 & 63.16 & $0.3-2.6$ \\
\hline 40 & OPQ-14 & 5'-GGACGCTTCA-3' & 17 & 03 & 14 & 82.35 & $0.1-2.9$ \\
\hline 41 & OPR-01 & 5'-CTTCCGCAGT-3' & 16 & 05 & 11 & 68.75 & $0.3-2.5$ \\
\hline 42 & OPR-02 & 5'-GGTGCGGGAA-3' & 14 & 07 & 07 & 50.00 & $0.3-2.5$ \\
\hline \multirow[t]{2}{*}{43} & OPR-03 & 5'-GACCTAGTGG-3' & 13 & 04 & 09 & 69.23 & $0.3-2.9$ \\
\hline & Total & & 563 & 190 & 373 & 66.46 & \\
\hline
\end{tabular}

TAF = Total amplified fragments, MF: monomorphic fragments, PF: polymorphic fragments, PIC (\%): percentages of polymorphism and Sm: specific marker fragments. 
The percent polymorphic loci (PIC \%) values ranged from $85.71 \%$ for primer OPA-20 to $42.85 \%$ for primer OPN-04. The PIC $\%$ between the six Acacia species using 43 RAPD primers was $66.46 \%$ (Table 4 and Figure 6).

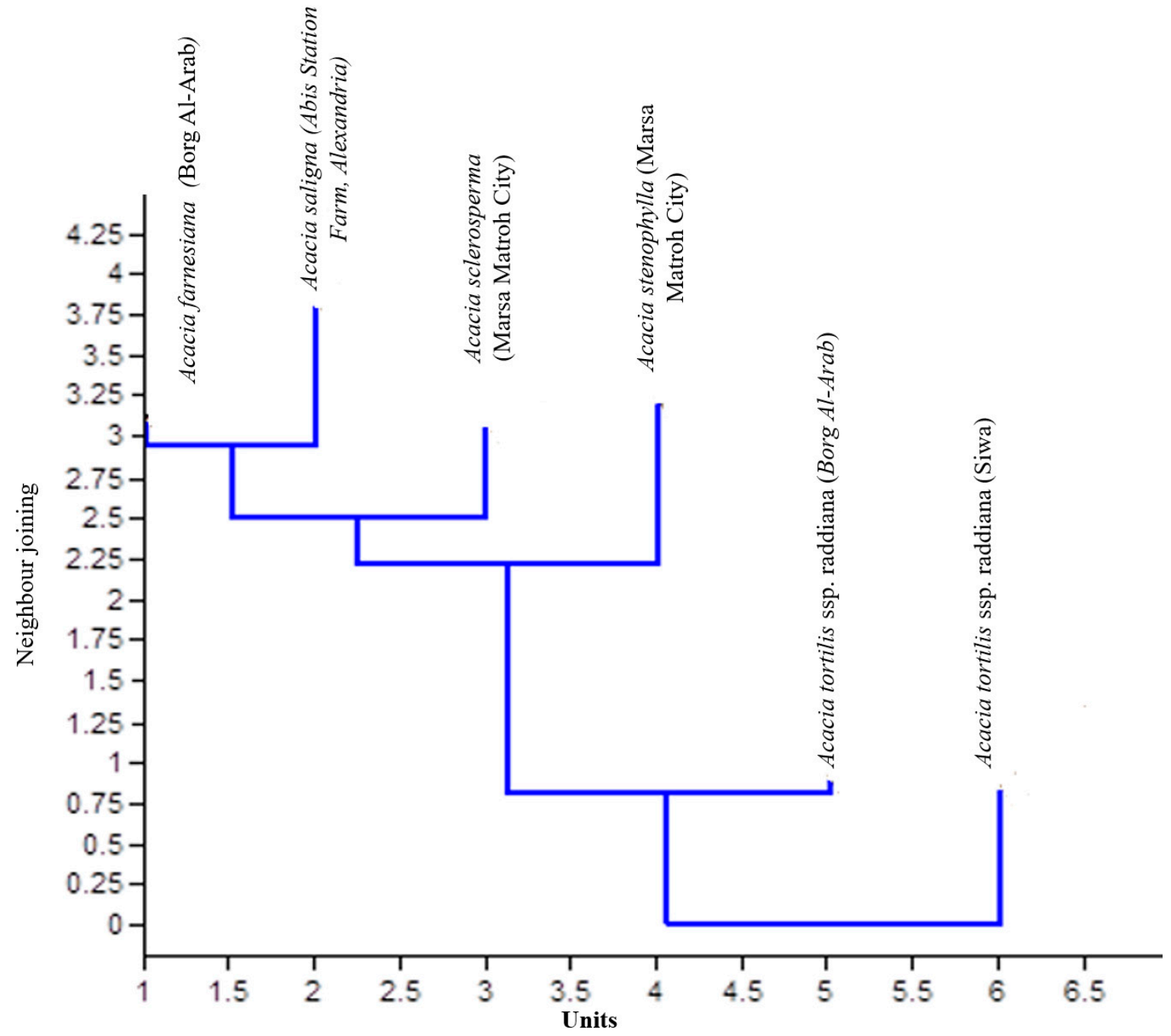

Figure 6. Dendrogram of similarity of different Acacia species based on forty-three RAPD primers.

\subsection{Genetic Similarity and Phylogenetic Relationships Among Acacia Species}

Genetic similarities and phylogenetic relationships among the six tested samples of Acacia species were examined using RAPD-PCR analysis, and the obtained data were subjected to cluster analysis with a Dice equation using SPSS (ver. 15) to calculate the proximity matrix and design dendrogram. Genetic similarity values generated from the RAPD markers varied between 0.60 and 0.78 , with an average of 0.69 . The dendrogram was based on similarity values (Table 5) from RAPD and was constructed using SPSS (ver. 15) to reveal similarities between the five different Acacia species. The dendrogram (Figure 6) demonstrated that the six Acacia spp. fell into three main groups. The first group included $A$. tortilis ssp. raddiana (Siwa Oasis), the second group included $A$. tortilis ssp. raddiana (Borg Al-Arab), and the third group included the other Acacia species. 
Table 5. Similarity indices (\%) among Acacia species based on 43 random amplified polymorphic DNA (RAPD) primers.

\begin{tabular}{ccccccc}
\hline Species & $\begin{array}{c}\text { A. Tortilis } \\
\text { (Siwa) }\end{array}$ & $\begin{array}{c}\text { A. Tortilis } \\
\text { Borg }\end{array}$ & A. Farnesiana & A.Stenophylla & A.Sclerosperma & A. Saligna \\
\hline A. tortilis (Siwa) & 1.00 & & & & & \\
\hline A. tortilis (Borg) & 0.78 & 1.00 & & & \\
\hline A. farnesiana & 0.74 & 0.71 & 1.00 & 1.00 & 1.00 & 1.00 \\
\hline A. stenophylla & 0.67 & 0.76 & 0.60 & 0.69 & 0.77 & 0.77 \\
\hline A. sclerosperma & 0.76 & 0.73 & 0.62 & & \\
\hline A. saligna & 0.67 & 0.72 & 0.60 & & & \\
\hline
\end{tabular}

RAPD-PCR markers are used routinely to identify genetic variations [64]. RAPD markers have also been used successfully in various taxonomic and phylogenetic studies by Kazan et al. [65] and Wilkie et al. [66]. As a molecular marker system, RAPD has also been successfully applied in cultivar identification. RAPD analysis is normally easy to perform, but it has a major disadvantage in that reproducibility is difficult to achieve between different laboratories, and often even between different people in the same laboratory. The previous results are consistent with Fagg and Allison [67], who reported variation in the chemical composition as well as molecular and morphological characteristics between Ugandan and Sudanese populations of $A$. senegal. Our results are in line with those of Shrestha et al. [68], who investigated A. raddiana populations and reported a great degree of polymorphism contrary to the conventional expectation of small, isolated populations. The maintenance of genetic variation is important because future evolutionary adaptation depends on the existence of genetic variation.

The PIC \% values obtained in this study were far higher than those observed in A. caven (29.4\%) [22], A. anomala (43\%) [69], and Faidherbia albida (42.7\%) [70]. However, similar results were obtained for Haloxylon ammodendron (74.9\%) by Sheng et al. [71] using ISSR markers, for Changium smyrnioides (69\%) by Fu et al. [72] using RAPD markers, and for F. albida (90\%) by Joly et al. [73] using isozymes.

\section{Materials and Methods}

\subsection{Leaf Samples}

Entire leaves of the following species were randomly collected from 20 individuals in natural Acacia tree habitats: A. tortilis ssp. raddiana collected from (Siwa Oasis) is an urban oasis in Egypt between the Qattara Depression and the Great Sand Sea in the Western Desert, nearly $50 \mathrm{~km}$ east of Libyan border and $650 \mathrm{~km}$ from Cairo, 29 $9^{\circ} 12^{\prime} 19$ N 25 $31^{\prime} 10 \mathrm{E}$ and (Borg El-Arab City, Alexandria, $48 \mathrm{~km}$

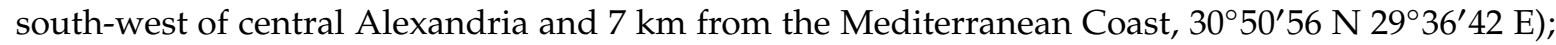
A. farnesiana (Borg El-Arab City); A. stenophylla (Marsa Matroh City, $240 \mathrm{~km}$ west of Alexandria and

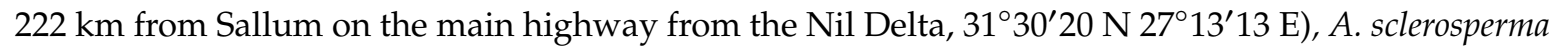
(Marsa Matroh City); and A. saligna (Abis Station Farm, Alexandria, $31^{\circ} 12 \mathrm{~N} 29^{\circ} 55 \mathrm{E}$ ).

\subsection{Morphological Analysis}

Four samples were collected for each parameter. The following morphological parameters were measured in the vegetative parts of the tree: pinna length $(\mathrm{cm})$, leaf length $(\mathrm{cm})$, leaflet length $(\mathrm{mm})$, and spine length $(\mathrm{mm})$ (if present) were measured with a millimetric ruler. Some qualitative characters were also recorded, such as crown shape (round, flat, spread, or undefined), growth habit, and number of stems counted from the ground level $(1,2-5$, or $>5)$. The spine shape observed in individual plants was determined to be either straight or mixed, i.e., straight and curved. 


\subsection{Biochemical Assays}

\subsubsection{Iso-Enzyme Electrophoresis}

Agar starch polyvinyl pyrolidine (PVP) gel electrophoresis was conducted according to the protocol described by Andrews [13]. The extracts were made by grinding young leaf tissue in a mortar with $10 \mu \mathrm{L}$ of electrode buffer and centrifuging for $15 \mathrm{~s}$; a $10 \mu \mathrm{L}$ sample of the homogenate was then absorbed onto a small rectangle (approximately $4 \times 2 \mathrm{~mm}$ ) of filter paper that was placed on the origin line of gel plates, which was removed after storage at $4{ }^{\circ} \mathrm{C}$ for $30 \mathrm{~min}$. The buffer was prepared by dissolving $92.75 \mathrm{~g}$ of $0.3 \mathrm{M}$ boric acid and $12 \mathrm{~g}$ sodium hydroxide in $5 \mathrm{~L}$ of distilled water; then, the solution was adjusted to $\mathrm{pH} 8.3$ according to Ahmed [74]. The gel buffer used was $0.07 \mathrm{M}$ Tris $0.007 \mathrm{M}$ citric acid, $\mathrm{pH}$ 8.3. One liter of the gel buffer was prepared by dissolving $9.21 \mathrm{~g}$ Tris and $1.05 \mathrm{~g}$ citric acid in distilled water and stored in a refrigerator until use. Ten grams of PVP gel were dissolved.

The mixture was vigorously shaken and cooked in a boiling water bath until the solution was transparent. The hot liquid gel was poured over glass plates $(20 \times 30 \mathrm{~cm})$ to produce a smooth surface layer with a thickness of $0.8-0.9 \mathrm{~mm}$ and stored at $4{ }^{\circ} \mathrm{C}$ until use [75]. The electrophoresis experiment was conducted in an incubated refrigerator set to $4{ }^{\circ} \mathrm{C}$ using a $250 \mathrm{~V}$ AC electrical current with constant voltage during the $90 \mathrm{~min}$ running period. A phosphate buffer $(0.1 \mathrm{M}, \mathrm{pH}=7.0)$ was used as a staining buffer by adding $39 \mathrm{~mL}$ of a $0.1 \mathrm{M}$ solution of monobasic sodium phosphate to $61 \mathrm{~mL}$ of a $0.1 \mathrm{M}$ solution of sodium dibasic phosphate and increasing the final volume to $200 \mathrm{~mL}$ using distilled water. Each gel was incubated in $100 \mathrm{~mL}$ phosphate buffer, $\mathrm{pH} 7.0$, containing $20 \mathrm{mg} \alpha$-naphthyl acetate ( $\alpha$-NA) and $20 \mathrm{mg} \beta$-naphthyl acetate (NA), dissolved in $1 \mathrm{~mL}$ acetone, and brought to $5 \mathrm{~mL}$ using distilled water. Fast blue RR salt $\left(\mathrm{C}_{15} \mathrm{H}_{14} \mathrm{ClN}_{3} \mathrm{O}_{3} \cdot 1 / 2 \mathrm{ZnCl}_{2}\right)(50 \mathrm{mg}$ dissolved in $5 \mathrm{~mL}$ distilled water) was added $3 \mathrm{~min}$ after the addition of $\alpha$ - and $\beta$-NA. This implies that an additional incubation was carried out for $30 \mathrm{~min}$ at $27-30^{\circ} \mathrm{C}$ under complete darkness. Plates were then washed with distilled water [76].

\subsubsection{Proline Content}

Proline was determined according to the method presented by Bates et al. [77]. The mixture was warmed by agitation until dissolved, then kept cool at $4{ }^{\circ} \mathrm{C}$ until use. A $0.5 \mathrm{~g}$ sample of leaf material was homogenized in $10 \mathrm{~mL}$ extraction buffer. The homogenate was filtered through Whatman filter paper No. 2, and $2 \mathrm{~mL}$ of filtrate was reacted with $2 \mathrm{~mL}$ acid ninhydrin and $2 \mathrm{~mL}$ glacial acetic acid in a test tube for $1 \mathrm{~h}$ at $100{ }^{\circ} \mathrm{C}$. The reaction was terminated using an ice bath. The reaction mixture was extracted with $4 \mathrm{~mL}$ of toluene mixed vigorously in a test tube with a stirrer for 15-20 s. The chromosphere containing toluene was aspirated from the aqueous phase, and the absorbance was determined using a spectrophotometer at $520 \mathrm{~nm}$ using toluene as a blank. The proline content was expressed as fresh weight on a standard curve, using standard L-proline according to the previous method developed by Hasan et al. [78]. Briefly, as follows: $\mu \mathrm{mol}$ proline $\mathrm{g}$ of fresh plant material $=$ [( $\mu \mathrm{g}$ proline $/ \mathrm{mL}^{-} \times \mathrm{mL}$ toluene $) / 115.5 \mu \mathrm{g} / \mu \mathrm{mol} /(\mathrm{g}$ sample/5)] [63].

\subsection{Molecular Analysis}

\subsubsection{Random Amplified Polymorphic DNA (RAPD) Analysis}

Fifty-two random amplified polymorphic DNA (RAPD) primers (10-mer primers) were initially screened using six Acacia species to determine the suitability of each primer for this study. Primers were selected for further analysis based on their ability to produce distinct, clearly resolved, and polymorphic amplified products between Acacia species. To ensure reproducibility, primers generating no, weak, or complex patterns were discarded [79]. DNA was extracted from $50 \mathrm{mg}$ samples of Acacia leaves using the DNeasy ${ }^{\circledR}$ Plant System (Operon Technologies Inc., Alameda, CA). The DNA extraction was modified, i.e., $700 \mu \mathrm{L}$ of warm (up to $65^{\circ} \mathrm{C}$ ) buffer AP1 for lyses was required during homogenization. Samples were centrifuged for $30 \mathrm{~s}$ at low speed $(4000 \times g)$, and $7 \mu \mathrm{L}$ of RNase A stock solution $\left(100 \mathrm{mg} \cdot \mathrm{mL}^{-1}\right)$ was mixed into each tube until no tissue clumps were visible. 
The mixture was incubated for $20 \mathrm{~min}$ at $65{ }^{\circ} \mathrm{C}$, and tubes were inverted twice during the incubation period. The addition of $228 \mu \mathrm{L}$ buffer AP2 to the lysate and incubation on ice for $5 \mathrm{~min}$ precipitated the detergent, proteins, and polysaccharides. The column-tube assembly was centrifuged at maximum speed for $2 \mathrm{~min}$ in a microcentrifuge. At least $500 \mu \mathrm{L}$ of clear filtrate was transferred to a $1.5 \mathrm{~mL}$ microfuge tube. Buffer AP3 and 100\% ethanol (1:2 v/v) were added to the lysate, and the solution was gently mixed by pipetting. $\mathrm{Up}$ to $650 \mu \mathrm{L}$ of the sample mixture (including any precipitate that formed) was applied to the DNeasy (Operon Technologies Inc., Alameda, CA) spin column, which was placed in a $2 \mathrm{~mL}$ collection tube. The assembly was centrifuged for $1 \mathrm{~min}$ at $12,000 \times g$, causing the DNA to be bound to the column membrane, and the filtrate was discarded. The remaining sample mixture was applied to the same column, and the procedure was repeated. The collection tube was replaced by a clean $2 \mathrm{~mL}$ tube, and the column was washed two to three times by adding $500 \mu \mathrm{L}$ buffer AW (containing ethanol) to the DNeasy column, centrifuging for $1 \mathrm{~min}$ at $12,000 \times g$, and discarding the filtrate.

Following the final wash, the column-tube assembly was centrifuged for $2 \mathrm{~min}$ at $12,000 \times g$ to dry the column membrane, and the collection tube was discarded. The DNeasy column was transferred to a clean $1.5 \mathrm{~mL}$ microcentrifuge tube, and DNA was eluted from the membrane by pipetting $100 \mu \mathrm{L}$ of preheated $\left(65^{\circ} \mathrm{C}\right)$ buffer AE directly onto the DNeasy column membrane. The sample was then incubated for $5 \mathrm{~min}$ and centrifuged for $1 \mathrm{~min}$ at $12,000 \times \mathrm{g}$ or higher. The elution step was repeated using the same microcentrifuge tube and yielded a final volume of $50 \mu \mathrm{L}$ DNA solution

\subsubsection{Polymerase Chain Reaction (PCR) Conditions}

RAPD analysis was conducted using 10 oligonucleotide primers that were selected from the Operon Kit (Operon Technologies Inc., Alameda, CA). The polymerase chain reaction (PCR) mixture $(25 \mu \mathrm{L})$ consisted of $0.8 \mathrm{U}$ of Taq DNA polymerase, $25 \mathrm{pmol} \mathrm{dNTPs}, 25 \mathrm{pmol}$ of primer, and $50 \mathrm{ng}$ of genomic DNA. PCR amplification was performed in a Biometra T1 gradient thermal cycler (Phoretix International, Newcastle upon Tyne, UK) for 40 cycles after initial denaturation for $3 \mathrm{~min}$ at $94^{\circ} \mathrm{C}$. Each cycle consisted of denaturation at $94^{\circ} \mathrm{C}$ for $1 \mathrm{~min}$, annealing at $36^{\circ} \mathrm{C}$ for $1 \mathrm{~min}$, extension at $72{ }^{\circ} \mathrm{C}$ for $2 \mathrm{~min}$, and a final extension at $72{ }^{\circ} \mathrm{C}$ for $10 \mathrm{~min}$ [79]. Amplification products were separated on $1 \%$ agarose gels at $100 \mathrm{~V}$ for $1.30 \mathrm{~h}$, using $1 \times \mathrm{TBE}$ buffer. To detect the ethidium bromide/DNA complex, agarose gels were examined using an ultraviolet transilluminator (302 nm wavelength); subsequently, the lengths of the different DNA fragments were determined. For each sample, the reproducible DNA bands from two runs were scored for their presence or absence. Fragment scoring and lane matching were performed automatically on digital images of the gels using Phoretix 1D Advanced version 4.00 (Phoretix International, Newcastle upon Tyne, UK).

All but the faintest bands were scored, and, where necessary, scores and matches were manually corrected.

Based on the matrix of genetic similarity values (peroxidase isozymes data) and the dendrogram was generated from PAleontological STatistics (PASTA) program that runs on standard Windows computers and is available free of charge. PAST integrates spreadsheet-type data entry with univariate and multivariate statistics, curve fitting, time series analysis, data plotting, and simple phylogenetic analysis. Many of the functions are specific to paleontology and ecology, and these functions are not found in standard, more extensive, statistical packages. PAST also includes fourteen case studies (data files and exercises), illustrating use of the program for paleontological problems, making it a complete educational package for courses in quantitative methods (http://palaeo-electronica.org).

\subsection{Statistical Analysis}

Data of the morphological variations of Acacia species were statistically analyzed with one-way analysis of variance (ANOVA) using the SAS system [80]. Comparisons among means were measured using $\operatorname{LSD}_{0.05}$. 


\section{Conclusions}

In the present study, genetic differentiation of some Acacia species growing in Egypt based on morphological, biochemical, and molecular markers were measured using twenty replicates of Acacia tree, collected from four different localities in Egypt. The results clearly indicated highly significant differences between Acacia species for morphological characteristics. In addition, the qualitative characteristics were used to detect the similarities and differences which are important in comparing the taxonomical grouping of Acacia species. RAPD-PCR proved to be a powerful tool for assessing the genetic diversity of several Acacia species in Egypt. Morphological parameters revealed highly significant variations among the Acacia species, confirming the hypothesis of the possibility of identification from such vegetative characteristics. Study of the genetic differentiation of Acacia species growing in Egypt is considered a primary step to genetic improvement in and documentation of this plant genetic resource in Egypt, especially Acacia tortilis ssp. Raddiana, which was collected from the isolated area Siwa Oasis in Egypt.

Author Contributions: N.R.A., H.M.A., M.Z.M.S., and H.E.E.-W. designed the experiments, conducted the laboratory analyses, wrote parts of the manuscript, and interpreted the results; all coauthors contributed to writing and revising the article. All authors have read and agreed to the published version of the manuscript.

Funding: This research was funded by Researchers Supporting Project number (RSP-2019/123) King Saud University, Riyadh, Saudi Arabia.

Acknowledgments: Researchers Supporting Project number (RSP-2019/123) King Saud University, Riyadh, Saudi Arabia. The authors also thank the Deanship of Scientific Research and RSSU at King Saud University for their technical support.

Conflicts of Interest: The authors declare no conflicts of interest.

\section{References}

1. Heywood, V.H. Conserving plants within and beyond protected areas-still problematic and future uncertain. Plant Divers. 2019, 41, 36-49. [CrossRef]

2. Albrecht, M.A.; Long, Q.G. Habitat suitability and herbivores determine reintroduction success of an endangered legume. Plant Divers. 2019, 41, 109-117. [CrossRef] [PubMed]

3. Shaw, T.E. Species diversity in restoration plantings: Important factors for increasing the diversity of threatened tree species in the restoration of the Araucaria forest ecosystem. Plant Divers. 2019, 41, 84-93. [CrossRef] [PubMed]

4. Ross, J.H. Analysis of the African Acacia species: Their distribution, possible origins and relationships. Bothalia 1981, 13, 389-413. [CrossRef]

5. Shaw, P.J.; Tononi, G.; Greenspan, R.J.; Robinson, D.F. Stress response genes protect against lethal effects of sleep deprivation in Drosophila. Nature 2002, 417, 287-291. [CrossRef] [PubMed]

6. Maslin, B. Proposed Name Changes in Acacia; Newsletter of the Australian Native Plant Society: Cremorne, NSW, Australian, 2003; Volume 38, pp. 12-18.

7. Maslin, B.R.; Miller, J.T.; Seigler, D.S. Overview of the generic status of Acacia (Leguminosae: Mimosoideae). Aust. Syst. Bot. 2003, 16, 1-18. [CrossRef]

8. Blakesley, D.; Allen, A.; Pellny, T.K.; Roberts, A.V. Natural and induced polyploidy in Acacia dealbata link and Acacia mangium Willd. Ann. Bot. 2002, 90,391-398. [CrossRef]

9. Khatoon, S.; Ali, S.I. Chromosome numbers and polyploidy in the legumes of Pakistan. Pak. J. Bot. 2006, 38, 935-945.

10. Vivi, T. Student's Flora of Egypt, 2nd ed.; Cairo University: Cairo, Egypt, 1974.

11. Bukhari, Y.M. Seed weight and protein concentration of whole seed, cotyledons and seed coat of 57 accessions of Acacia and Prosopis (Mimosaceae): Phylogenetic and nutritional implications. Indian For. 2002, 128, 686-699.

12. Prakash, D.; Niranjan, A.; Tewari, S.K.; Pushpangadan, P. Underlisted legumes: Potential sources for low-coast protein. Int. J. Food Sci. Nutr. 2001, 52, 337-341. [CrossRef]

13. Andrews, A.T. Electrophoresis: Theory, Techniques and Biochemical and Clinical Application; Oxford Science Publications, Monographs on Physical Chemistry, Clarendon Press: Oxford, UK, 1981; p. 452. 
14. Abogadallah, G.M. Antioxidative defense under salt stress. Plant Signal. Behav. 2010, 5, 369-374. [CrossRef]

15. Persson, K.; Falt, A.S.; Von Bothmer, R. Genetic diversity of allozymes in turnip (Brassica rapa L. var. rapa) from the Nordic area. Hereditas 2001, 134, 43-52. [CrossRef]

16. Rahman, M.H. Introgression of alleles of the isozymic locus glucose- phosphate isomerase-2 (GPI-2) from the CC genome of Brassica carinata to the CC genome of Brassica alboglabra and their independent segregation from seed color. Plant Breed. 2001, 120, 363-364. [CrossRef]

17. Bowles, D.J. Defense-related proteins in higher plants. Ann. Rev. 1990, 59, 873-907. [CrossRef]

18. Kalir, A.; Omri, G.; Poljakoff-Mayber, A. Peroxidase and catalase activity in leaves of Halimione portulacoides exposed to salinity. Physiol. Plant. 1984, 62, 238-244. [CrossRef]

19. Wisal, S.; Khan, A.; Gul, K.; Khan, W.; Nigar, G.; Ali, M. Assessing genetic variability index among species of ACACIA through morphological and biochemical markers. Int. J. Biosci. 2019, 14, 388-401.

20. Gaspar, T.; Penel, C.; Thorpe, T.; Greppin, H. Peroxidases 1970-1980; A Survey of Their Biochemical and Physiological Roles in Higher Plants; University of Geneva: Geneva, Switzerland, 1982.

21. Scandalios, J.G. Regulation and properties of plant catalases. In Causes of Photooxidative Stress and Amelioration of Defense Systems in Plants; Foyer, C.H., Mullineaux, P.M., Eds.; CRC Press: Boca Raton, FL, USA, 1994; pp. 275-315.

22. Casiva, P.V.; Saidman, B.O.; Vilardi, J.C.; Cialdella, A.M. First comparative phenetic studies of Argentinean species of Acacia (Fabaceae), using morphometric isozymal and RAPD approaches. Am. J. Bot. 2002, 89, 843-853. [CrossRef]

23. Boggess, S.F.; Stewart, C.R. The relationship between water stress induced proline accumulation and inhibition of protein synthesis in tobacco leaves. Plant Sci. Lett. 1980, 17, 245-252. [CrossRef]

24. Palfi, G.; Juhasz, J. The theoretical basis and practical application of a new method of selection for determining water deficiency in plants. Plant Soil 1971, 34, 503-507. [CrossRef]

25. Yoshiba, Y.; Kiyosue, T.; Nakashima, K.; Yamaguchi-Shinozaki, K.Y.; Shinozaki, K. Regulation of levels of proline as an osmolyte in plants under water stress. Plant Cell Physiol. 1997, 38, 1095-1102. [CrossRef]

26. Buhl, M.B.; Stewart, S.R. Effects of $\mathrm{NaCl}$ on proline synthesis and utilization in excised barley leaves. Plant Physiol. 1983, 72, 664-667. [CrossRef]

27. Pedley, L. Derivation and dispersal of Acacia (Leguminosae), with particular reference to Australia, and the recognition of Senegalia and Racosperma. Bot. J. Linn. Soc. 1986, 92, 219-254. [CrossRef]

28. Clarke, H.D.; Downi, S.R.; Seigler, D.S. Implications of chloroplast DNA restriction site variation for systematics of Acacia (Fabaceae: Mimosoideae). Syst. Bot. 2000, 25, 618-632. [CrossRef]

29. Butcher, P.A.; Moran, G.F.; Perkins, H.D. RFLP diversity in the nuclear genome of Acacia mangium. Hereditas 1998, 81, 205-213. [CrossRef]

30. Hollingsworth, P.M.; Bateman, R.M.; Gornall, R.J. Molecular Systematics and Plant Evolution; Taylor and Francis: London, UK, 1999.

31. Cottrell, J.E.; Forrest, G.I.; White, I.M.S. The use of random amplified polymorphic DNA markers to identify and estimate the relatedness of clones belonging to the genus Populus. Bot. J. Scotl. 1997, 49, 89-102. [CrossRef]

32. Billionnet, A. Quantifying extinction probabilities of endangered species for phylogenetic conservation prioritization may not be as sensitive as might be feared. Biodivers. Conserv. 2018, 27, 1189-1200. [CrossRef]

33. Attia, A.O.; Al-Sodany, Y.M. Ecological Distribution and Genetic Variations of Some Aloe Species in Taif, KSA. Sciences 2019, 22, 623-629. [CrossRef]

34. Asaf, S.; Khan, A.; Khan, A.L.; Al-Harrasi, A.; Al-Rawahi, A. Complete Chloroplast Genomes of Vachellia nilotica and Senegalia senegal: Comparative Genomics and Phylogenomic Placement in a New Generic System. PLoS ONE 2019, 14, e0225469. [CrossRef]

35. Ramirez, R.G.; Neira-Morales, R.R.; Torres-Noriega, K.A. Rumen digestion of the protein of seven shrubs native to the Northeast of Mexico. Phyton 2000, 67, 29-35.

36. Byrne, M.; Tischler, G.; MacDonald, B.; Coates, D.J.; Mc Comb, J. Phylogenetic relationships between two rare acacias and their common, widespread relatives in south- western Australia. Conserv. Genet. 2011, 2, 157-166. [CrossRef]

37. Abdelsalam, N.R.; Ali, H.M.; Salem, M.Z.M.; Ibrahem, E.G.; Elshikh, M.S. Genetic and Morphological Characterization of Mangifera indica L. Growing in Egypt. HortScience 2018, 53, 1266-1270. [CrossRef] 
38. Wachira, F.N.; Tanaka, J.; Takeda, Y. Genetic variation and differentiation in tea (Camellia sinensis) germplasm revealed by RAPD and AFLP variation. J. Hortic. Sci. Biotechnol. 2001, 76, 557-563.

39. Fernandez, A.; Schutzki, R.E.; Hancock, J.F. Isozyme and morphological variation in a Cornus florida L. Provenance plantation and representing geographically diverse populations. J. Am. Soc. Hortic. Sci. 1996, 121, 225-230. [CrossRef]

40. Culpepper, J.H.; Sayavedra-Soto, L.A.; Bassam, B.J.; Gresshoff, P.M. Characterization of Cornus (Dogwood) genotypes using DNA fingerprinting. J. Am. Soc. Hortic. Sci. 1991, 116, 1103-1107. [CrossRef]

41. Bretting, P.K.; Widrelechner, M.P. Genetic markers and horticultural germplasm management. HortScience 1995, 30, 1349-1356. [CrossRef]

42. Sajadi, S.; Shiran, B.; Kharazian, N.; Houshmand, S.; Sorkheh, K. Genetic diversity of Salvia species from Chaharmahal va Bakhtiari and Isfahan province using AFLP molecular markers. J. Hortic. Sci. 2010, 40, 79-88.

43. Rout, G.R.; Senapati, S.K.; Aparajeta, S. Micropropagation of Acacia chundra (Roxb.) DC. Hort. Sci. 2008, 35, 22-26. [CrossRef]

44. Vicente, S.; Máguas, C.; Trindade, H. Genetic diversity and differentiation of invasive Acacia longifolia in Portugal. Web Ecol. 2018, 18, 91-103. [CrossRef]

45. Assoumane, A.A.; Vaillant, A.; Mayaki, A.Z.; Verhaegen, D. Isolation and characterization of microsatellite markers for Acacia senegal (L.) Willd, a multipurpose arid and semi-arid tree. Mol. Ecol. Resour. 2009, 9, 1380-1383. [CrossRef]

46. Brown, G.K.; Clowe, C.; Murphy, D.J.; Ladiges, P.Y. Phylogenetic analysis based on nuclear DNA and morphology defines a clade of eastern Australian species of Acacia ss. (section Juliflorae): The "Acacia longifolia group". Aust. Syst. Bot. 2010, 23, 162-172. [CrossRef]

47. Brown, G.; Murphy, D.J.; Kidman, J.; Ladiges, P.Y. Phylogenetic connections of phyllodinous species of Acacia outside Australia are explained by geological history and human-mediated dispersal. Aust. Syst. Bot. 2012, 25, 390-403. [CrossRef]

48. Fernandes, P.; Antunes, C.; Correia, O.; Máguas, C. Do climatic and habitat conditions affect the reproductive success of an invasive tree species? An assessment of the phenology of Acacia longifolia in Portugal. Plant Ecol. 2015, 216, 343-355. [CrossRef]

49. Fredua-Agyeman, R.; Adamski, D.; Liao, R.J.; Morden, C.; Borthakur, D. Development and characterization of microsatellite markers for analysis of population differentiation in the tree legume Acacia koa (Fabaceae: Mimosoideae) in the Hawaiian Islands. Genome 2008, 51, 1001-1015. [CrossRef]

50. Harris, C.J.; Dormontt, E.E.; Le Roux, J.J.; Lowe, A.; Leishman, M.R. No consistent association between changes in genetic diversity and adaptive responses of Australian acacias in novel ranges. Evol. Ecol. 2012, 26, 1345-1360. [CrossRef]

51. Josiah, C.C.; George, D.O.; Eleazar, O.M.; Nyamu, W.F. Genetic diversity in Kenyan populations of Acacia senegal (L.) willd revealed by combined RAPD and ISSR markers. Afr. J. Biotechnol. 2008, 7, 2333-2340.

52. Omondi, S.F.; Kireger, E.; Dangasuk, O.G.; Chikama, B.; Odee, D.W.; Cavers, S.; Khasa, D.P. Genetic diversity and population structure of Acacia senegal (L) Willd. in Kenya. Trop. Plant Biol. 2010, 3, 59-70. [CrossRef]

53. Mulumba, J.; Nyakaana, S.; Jamnadass, R. Genetic Diversity and Structure of Acacia senegal (L.) Willd. in Uganda. Int. J. Bot. 2012, 8, 107-116. [CrossRef]

54. Murphy, D.J.; Brown, G.K.; Miller, J.T.; Ladiges, P.Y. Molecular phylogeny of Acacia s.s. (Mimosoideae: Leguminosae)-evidence for major clades and informal classification. Taxon 2010, 59, 7-19. [CrossRef]

55. Omondi, S.F.; Odee, D.W.; Ongamo, G.O.; Kanya, J.I.; Khasa, D.P. Genetic consequences of anthropogenic disturbances and population fragmentation in Acacia senegal. Conserv. Genet. 2016, 17, 1235-1244. [CrossRef]

56. Otero-Arnaiz, A.; Schnabel, A.; Glenn, T.C.; Schable, N.A.; Hagen, C.; Ndong, L. Isolation and characterization of microsatellite markers in the East African tree, Acacia brevispica (Fabaceae: Mimosoideae). Mol. Ecol. Notes 2005, 5, 366-368. [CrossRef]

57. Pometti, C.L.; Bessega, C.F.; Vilardi, J.C.; Ewens, M.; Saidman, B.O. Genetic variation in natural populations of Acacia visco. Plant Syst. Evol. 2016, 302, 901-910. [CrossRef]

58. Taylor, D.B.; Dhileepan, K. Implications of the changing phylogenetic relationships of Acacia sl on the biological control of Vachellia nilotica ssp. indica in Australia. Ann. Appl. Biol. 2019, 174, 238-247. [CrossRef] 
59. Monks, L.; Barrett, S.; Beecham, B.; Byrne, M.; Chant, A.; Coates, D.; Yates, C. Recovery of threatened plant species and their habitats in the biodiversity hotspot of the Southwest Australian Floristic Region. Plant Divers. 2019, 41, 59-74. [CrossRef]

60. El Ayadi, F.; Aabd, N.A.; El Finti, A.; Msanda, F.; Baniaameur, F.; El Mousadik, A. Genetic variability of Wild Provenances of Acacia tortilis ssp. raddiana (Savi) Brenan in South of Morocco. Asian J. Plant. Sci. 2011, 10, 43-51. [CrossRef]

61. Cronk, Q.C.; Fuller, J.L. Plant Invaders: The Threat to Natural Ecosystems; Royal Botanic Gardens: Kew, UK; Springer: Berlin/Heidelberg, Germany, 1995; ISBN 0-412-48380-7.

62. Duangpan, S.; Sujitto, S.; Eksomtramage, T. Genotypic variation in proline accumulation during sequential drought and rewatering in response to drought preconditioning. Int. J. Agric. Technol. 2007, 13, 927-940.

63. Ahmed, J.; Hasan, M. Evaluation of seedling proline content of wheat genotypes in relation to heat tolerance. Bangladesh J. Bot. 2011, 40, 17-22. [CrossRef]

64. Sun, Q.; Ni, Z.; Litu, Z.; Gao, J.; Huang, T. Genetic relationships and diversity among Tibelian whets, common wheat and European spelt wheat revealed by RAPD markers. Euphytica 1998, 99, 205-211. [CrossRef]

65. Wilkie, S.E.; Isaac, P.G.; Slater, R.J. Random amplified polymorphic DNA (RAPD) markers for genetic analysis in Allium. Theor. Appl. Genet. 1993, 86, 497-504. [CrossRef]

66. Kazan, K.; Manners, J.M.; Cameron, D.F. Genetic relationship and variation in the Stylosanthes guianensis species complex assessed by random amplified polymorphic DNA. Genome 1993, 36, 43-49. [CrossRef]

67. Fagg, C.W.; Allison, G.E. Acacia Senegal and the Gum Arabic Trade, Monograph and Annotated Bibliog-Raphy; Tropical Forestry Papers No. 42; Oxford Forestry Institute: Oxford, UK, 2004.

68. Shrestha, M.K.; Ward, D.; Golan-Goldhirsh, A. Genetic diversity and water stress in isolated Negev desert populations of Acacia raddiana. In Proceedings of the Communicating and Advancing Ecology, The Ecological Society of America 85th Annual Meeting (Abstract), Snowbird, UT, USA, 6-10 August 2000; p. 337.

69. Coates, D.J. Genetic diversity and population genetic structure in the rare Chittering grass wattle Acacia anomala. Aust. J. Bot. 1988, 36, 273-286. [CrossRef]

70. Dangasuk, O.G.; Gudu, S. Allozyme variation in 16 natural populations of Faidherbia albida (Del.) A. Chev. Hereditas 2000, 133, 133-145. [CrossRef]

71. Sheng, Y.; Zheng, W.; Pei, K.; Ma, K. Genetic variation within and among populations of a dominant desert tree Haloxylon ammodendron (Amaranthaceae) in China. Ann. Bot. 2005, 96, 245-252. [CrossRef]

72. Fu, C.; Qiu, Y.; Kong, H. RAPD analysis for genetic diversity in Changium smyrnioides (Apiaceae), an endangered plant. Aust. J. Bot. 2003, 36, 263-276.

73. Joly, H.I.; Zeh-Nio, M.; Danthu, P.; Aygalent, C. Population genetics of an African acacia: Acacia albida. Genetic diversity of populations from West Africa. Aust. J. Bot. 1992, 40, 59-73. [CrossRef]

74. Ahmed, E.S.E. The Parallel Response of Enzyme Loci in Drosophila and Yeast to the Environmental Stresses of Pollutants. Master's Thesis, Faculty of Agriculture, Ain Shams University, Amsterdam, The Netherlands, 1994.

75. EL-Metainy, A.Y.; Abou-Youssef, A.Y.; El-Hadad, M. Starch degrading isozymes in Triticumn aestivum, Triticumn pyramidal, and their interspecific hybrid. Egypt J. Genet. Cytol. 1977, 6, 375-379.

76. Youssef, M.K.; Badr, E.A.; Abou-Youssef, A.; El-Deeb, S. Comparative electrophoretic pattern of isozymes in four species of tilapia. In Proceedings of the Third Egyptian British Conference on Animal, Fish and Poultry Production, Alexandria, Egypt, 7-10 October 1989; pp. 849-858.

77. Bates, L.S.; Waldren, R.P.; Tear, L.D. Rapid determination of free proline for water-stress studies. Plant Soil 1973, 39, 205-207. [CrossRef]

78. Hasan, M.A.; Ahmed, J.U.; Bahadur, M.M.; Haque, M.M.; Sikder, S. Effect of late planting heat stress on membrane thermostability, proline content and heat susceptibility index of different wheat cultivars. J. Natl. Sci. Found. Sri Lanka 2007, 35, 109-117. [CrossRef]

79. Williams, J.G.K.; Kubelik, A.R.; Livak, K.J.; Rafalski, J.A.; Tingey, S.V. DNA polymorphisms amplified by primers are useful as genetic markers. Nucleic Acids Res. 1990, 18, 6531-6535. [CrossRef]

80. Statistical Analysis Software (SAS). User Guide: Statistics; Release 8.02; SAS Institute: Cary, NC, USA, 2001.

(C) 2020 by the authors. Licensee MDPI, Basel, Switzerland. This article is an open access article distributed under the terms and conditions of the Creative Commons Attribution (CC BY) license (http://creativecommons.org/licenses/by/4.0/). 